\title{
BASELINE GEOCHEMICAL ASSESSMENT OF METAL CONCENTRATION AND DISTRIBUTION IN TOP SOILS OF THE FREE-TRADE ZONE, AKODO, IBEJU- LEKKI AREA, SOUTH-WESTERN NIGERIA
}

\author{
AJAYIF.F. ${ }^{*}$ AND SABITU R. A. ${ }^{2}$ \\ ${ }^{1}$ Department of Geology, University of Ibadan, Ibadan, Nigeria \\ (*Correspondence: felifunmi@gmail.com) \\ ${ }^{2}$ Department of Geology, University of Ibadan, Ibadan, Nigeria \\ (aderinolaruqayaah@gmail.com)
}

\section{INTRODUCTION}

Most studies evaluating the concentration of trace metals in Urban and Industrialized regions usually show high levels of heavy metals in sampled media. These levels are attained before being noticed due to lack of data on background concentrations especially in developing countries. This study was carried-out, in a bid to aid research, proactively monitor and control pollution from heavy metals in the future, by providing information on the background concentrations in a proposed industrial area of International status (The Lekki Free-Trade Zone)

\section{METHODOLOGY AND RESULTS}

Thirty (30) topsoil samples were randomly obtained, dried at room temperature and then sieved to $<75 \mu \mathrm{m}$ fractions. These fractions were subsequently analyzed for heavy metal contents using a flame Atomic Absorption Spectrophotometer. Results obtained were then geochemically and statistically evaluated.

Concentration range, in ppm, for selected metals were; $\mathrm{Pb}(90.20-$ 147.15), Zn $(6-28)$, Cd $(5.25$ - 9.35), Cu (55 - 80), Co (51.95 182.5), Mn (2 - 137). Geoaccumulation index indicated the sampled areas were generally unpolluted by $\mathrm{Pb}, \mathrm{Zn}, \mathrm{Cd}, \mathrm{Cu}, \mathrm{Co}$, and $\mathrm{Mn}$ indicated non-pollution to moderate pollution in specific areas. Values for Contamination factors mimic the aforementioned pattern. Pollution Load Index (PLI) for most locations had baseline level of pollution, a few were deteriorated in quality while the remaining were of perfect quality.

The topsoil around Akodo, Ibeju-Lekki and the Lekki Free-Trade Zone (LFTZ) have low levels of heavy metals, while $\mathrm{Pb}$ is moderate; this largely due to the heavy presence of automobile repairing and Iron smelting workshops in the area. 
